\title{
Chronic Low-Dose L-NAME Treatment Increases Nitric Oxide Production and Vasorelaxation in Normotensive Rats
}

\author{
I. BERNÁTOVÁ ${ }^{1}$, J. KOPINCOVÁ ${ }^{1}$, A. PÚZSEROVÁ ${ }^{1}$, P. JANEGA ${ }^{1,2}$, \\ P. BABÁL ${ }^{2}$ \\ ${ }^{1}$ Institute of Normal and Pathological Physiology, Centre of Excellence for Cardiovascular \\ Research, Slovak Academy of Sciences, ${ }^{2}$ Department of Pathological Anatomy, Faculty of \\ Medicine, Comenius University, Bratislava, Slovak Republic
}

Received July 4, 2007

Accepted August 28, 2007

On-line available September 5, 2007

\begin{abstract}
Summary
$\mathrm{N}^{\mathrm{G}}$-nitro-L-arginine methyl ester (L-NAME) is a non-specific nitric oxide (NO) synthase inhibitor, commonly used for the induction of NO-deficient hypertension. The aim of this study was to investigate the effect of chronic low-dose administration of L-NAME on NO production, vascular function and structure of the heart and selected arteries of rats. Adult male Wistar rats were treated with L-NAME in the dose of approximately $1.5 \mathrm{mg} / \mathrm{kg} /$ day in drinking water for 8 weeks. Basal blood pressure (BP) of rats (determined by tail-cuff) was $112 \pm 3 \mathrm{~mm} \mathrm{Hg}$. The low-dose administration of L-NAME significantly elevated BP measured on the third and sixth week of treatment $v s$. controls by approximately $9 \%$ and $12 \%$, respectively. After this period, BP of L-NAME-treated rats returned to the control values. The relative left ventricular mass, heart fibrosis and collagen III/collagen I ratio were not affected by L-NAME. Similarly, there were no alterations in the cross-sectional area and wall thickness/diameter ratio of the aorta and the femoral artery of LNAME-treated rats. NO synthase activity (determined by conversion of $\left[{ }^{3} \mathrm{H}\right]$-L-arginine to $\left[{ }^{3} \mathrm{H}\right]$-L-citrulline) was not altered in the hypothalamus of L-NAME-treated rats. Interestingly, chronic low-dose L-NAME treatment significantly elevated NO synthase activity in the left ventricle and aorta, increased endothelium-dependent acetylcholine-induced vasorelaxation and reduced serotonin-induced vasoconstriction of the femoral artery. The data suggest that chronic lowdose L-NAME treatment can increase NO production and vasorelaxation in normotensive rats without negative structural changes in the cardiovascular system.
\end{abstract}

\section{Key words}

Hypertension $\bullet$ Blood pressure $\bullet$ Cardiac and vascular structure $\bullet$ Negative feedback regulation $\bullet$ Acetylcholine $\bullet$ Serotonin

\section{Introduction}

Nitric oxide is a widespread biological mediator produced in various tissues by one of four isoforms of nitric oxide (NO) synthase (Guix et al. 2005, Šimko 2007). Besides its role in neurotransmission and hemodynamic control, NO participates in the regulation of cell proliferation and growth (Pecháňová and Šimko 
2007). It has been shown that chronic pharmacological reduction of NO synthesis with the NO synthase (NOS) inhibitor $\mathrm{N}^{\mathrm{G}}$-nitro-L-arginine methyl ester (L-NAME) resulted in metabolic alterations, hypertension and myocardial hypertrophy (Bernátová et al. 1999b, Šimko and Šimko 2000, Kuneš et al. 2004), reduced vasorelaxation (Bernátová et al. 2002, Gerová et al. 2004, Török and Kristek 2002, Paulis et al. 2006) as well as to vascular wall thickening (Bernátová et al. 1999a, Gerová and Kristek 2001, Šimko et al. 2007a). Additionally, the reduction of NO synthesis led to remodelling of myocyte junctions (Fialová et al. in press), angiogenesis, mitochondrial damage (Okruhlicová et al. 2000, Tribulová et al. 2000) and myocardial fibrosis (Babál et al. 1997, Pecháňová et al. 1999).

Although the model of L-NAME-induced hypertension has been one of the most frequently used models of experimental hypertension since 1990, there is little information on the effects of chronic low-dose LNAME treatment (less than $2 \mathrm{mg} / \mathrm{kg}$ /day) on the cardiovascular system. This issue may be particularly important because several studies have provided evidence for the negative-feedback regulatory role of $\mathrm{NO}$ on endothelial NOS, and therefore on vascular function (Cohen et al. 1996, Griscavage et al. 1995, Vaziri and Wang 1999). Additionally, negative feedback regulation by NO was observed also for nNOS and iNOS (Park et al. 1997, Vickroy and Malphurs 1995). However, the above mentioned studies investigated the effects of exogenous NO donors on NO production in vitro or in acute experiments. Thus the question arose whether chronic reduction of NO bioavailability in vivo may activate NO production.

The purpose of this study was to investigate the effect of long-term low-dose L-NAME treatment on NO production, vascular function and cardiovascular structure of normotensive rats.

\section{Methods}

\section{Animals and treatment}

Male 12-week-old Wistar rats were randomly divided into a control $(\mathrm{n}=8)$ and an L-NAME-treated group $(n=7)$. L-NAME was administered orally in tap water for eight weeks. All rats were housed at $22-24{ }^{\circ} \mathrm{C}$ on a 12:12-h dark-light cycle (06.00-18.00h lights on) and had food and water (or L-NAME solution) ad libitum. The concentration of L-NAME in tap water was calculated on the basis of body mass and drinking volume of rats to reach approximately the daily dose of 1.5 $\mathrm{mg} / \mathrm{kg} /$ day L-NAME. The calculated average daily dose of L-NAME was $1.49 \pm 0.053 \mathrm{mg} / \mathrm{kg} / \mathrm{day}$. All procedures used in this study were approved by the State Veterinary and Food Administration of the Slovak Republic.

One week before experimentation, the rats were handled and accustomed to the tail-cuff procedure of blood pressure recording. Blood pressure (BP) was determined before experiment (basal) and on the 1st, 3rd, 6th and 8th week of experiment. After 8 weeks of experiment, the rats were killed by decapitation following a brief diethyl ether anaesthesia. Body mass (BM) as well as the wet mass of the left (LV) and the right ventricle (RV) were determined for calculation of their relative masses (LV/BM, RV/BM).

\section{NO synthase activity}

NO synthase activity was measured in the homogenates of the hypothalamus, thoracic aorta and the left ventricle by determination of $\left[{ }^{3} \mathrm{H}\right]$-L-citrulline (L-Cit) formation from $\left[{ }^{3} \mathrm{H}\right]$-L-arginine (MP Biomedicals, USA), as previously described (Bredt and Snyder 1990), with minor modifications. Briefly, crude homogenates of the aorta and LV containing $200 \mathrm{mg}$ of wet tissue in $1 \mathrm{ml}$ of homogenization solution containing $50 \mathrm{mmol} / \mathrm{l}$ Tris- $\mathrm{HCl}$, pH 7.4 and $1 \%$ Protease Inhibitor Cocktail (Sigma, Germany) were centrifuged at $10000 \mathrm{~g}$ for $15 \mathrm{~min}$ at $4{ }^{\circ} \mathrm{C}$. After centrifugation, $50 \mu \mathrm{l}$ of supernatant was incubated in the presence of $10 \mu \mathrm{mol} / 1\left[{ }^{3} \mathrm{H}\right]$-L-arginine (specific activity $5 \mathrm{GBq} / \mathrm{mmol}$, about $100000 \mathrm{DPM}$ ), 5 $\mu \mathrm{g} / \mathrm{ml}$ calmodulin, $0.5 \mathrm{mmol} / 1 \quad \beta-\mathrm{NADPH}, 250 \mu \mathrm{mol} / \mathrm{l}$ tetrahydrobiopterin, $4 \mu \mathrm{mol} / 1 \mathrm{FAD}, 4 \mu \mathrm{mol} / 1 \mathrm{FMN}$, $1 \mathrm{mmol} / \mathrm{l} \mathrm{Ca}^{2+}, 1 \mathrm{mmol} / \mathrm{M} \mathrm{Mg}^{2+}$, in the total volume of $100 \mu$ l. After 20 -min incubation at $37^{\circ} \mathrm{C}$, the reaction was stopped by $1 \mathrm{ml}$ of ice-cold stop solution containing $20 \mathrm{mmol} / 1$ HEPES, pH 5.5, 2 mmol/1 EDTA, 2 mmol/1 EGTA and $1 \mathrm{mmol} / 1$ L-Cit and applied to 50WX-8 Dowex columns $\left(\mathrm{Na}^{+}\right.$form). $\left[{ }^{3} \mathrm{H}\right]$-L-citrulline was eluted by $1 \mathrm{ml}$ of water and determined by liquid scintillation counting. NO synthase activity was expressed as pmol/min/mg of proteins.

\section{Vascular responses}

Femoral arteries were carefully excised, cleaned of adipose and connective tissue, cut into segments (approximately $1 \mathrm{~mm}$ long) and mounted as ring-shaped preparations in a Mulvany - Halpern's small vessel myograph chamber (Dual Wire Myograph System 410A, DMT A/S, Aarhus, Denmark) to determine the vascular 
reactivity during isometric conditions in the arteries with intact endothelium, as described elsewhere (Púzserová et al. 2006a). Endothelium-dependent vasorelaxation was determined after pre-constriction of the segments with phenylephrine $\left(10^{-4} \mathrm{~mol} / \mathrm{l}\right)$. Acetylcholine was applied in cumulative manner $\left(10^{-9}-10^{-5} \mathrm{~mol} / \mathrm{l}\right)$ when the contractile response to phenylephrine reached a plateau, and the extent of relaxation was expressed as the percentage of pre-contraction. Other segments of the arteries were used to test contractile responses of the arteries induced by serotonin (5-hydroxytryptamine). Serotonin was applied in cumulative manner $\left(10^{-9}-10^{-5} \mathrm{~mol} / \mathrm{l}\right)$ and the extent of vasoconstriction was expressed as $\mathrm{mN} / \mathrm{mm}$.

\section{Morphological analysis}

Samples of the heart, aorta and femoral artery were fixed for one day in $4 \%$ formaldehyde (Sigma Chemie, Germany). Fixed tissue samples were embedded in paraffin, cut in $5 \mu \mathrm{m}$ slices and stained routinely with hematoxylin and eosin. Modified picrosirius red staining technique (Dolber and Spach 1993) was used to determine the level of fibrosis. Briefly, after deparaffinization in xylene and rehydration in distilled water, the slides were incubated for $5 \mathrm{~min}$ in $0.2 \%$ aqueous solution of phosphomolybdic acid (Sigma Chemie, Germany) and stained with $0.1 \%$ sirius red in saturated solution of picric acid (Sigma Chemie, Germany) for $90 \mathrm{~min}$. Finally the slides were washed for two minutes in $0.01 \mathrm{~mol} / 1$ hydrochloric acid. Total fibrosis of each tissue sample was measured by histomorphometry in 10 microscopic fields at $20 \mathrm{x}$ magnification. Results are expressed as permille of collagen positivity of the total analyzed area. The area rich for collagen type I (red color in polarized light) and collagen type III (green color in polarized light) was analyzed by the digital color subtraction, and the ratio of collagen type III to collagen type I was determined.

The standard morphometric analysis of the aorta and femoral artery was realized on hematoxylin and eosin-stained slides. The cross-sectional area (CSA) expressed in $\mu \mathrm{m}^{2}$ and the wall thickness to internal diameter ratio of vessels were measured using the ImageJ morphometric software v.1.33 (National Institutes of Health, USA).

\section{Statistical analysis}

Blood pressure and vascular responses were analyzed using two-way ANOVA. Significant differences were identified by Duncan's post-hoc test. All other data

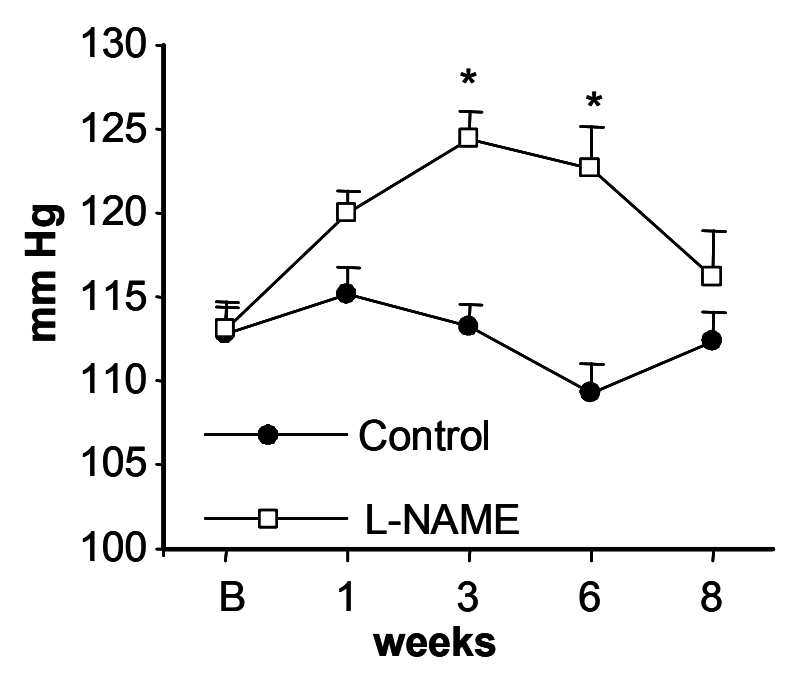

Fig. 1. Effect of chronic low-dose L-NAME treatment on blood pressure of normotensive rats. Results are presented as mean \pm SEM. ${ }^{*} \mathrm{p}<0.001$ vs. control. B - basal value

were analyzed by Student's t-test. Values were considered to differ significantly when $\mathrm{p}<0.05$. All results are presented as mean \pm SEM.

\section{Results}

Blood pressure and morphological parameters

Basal blood pressure of all rats before experiment was $112 \pm 3 \mathrm{~mm} \mathrm{Hg}$ (Fig. 1). Low-dose L-NAME administration resulted in a transient elevation of BP at the 3rd and 6th week by approximately $9 \%$ and $12 \% \quad v s$. control value $(\mathrm{p}<0.001)$. However, normalization of BP was observed after eight weeks of LNAME treatment.

The relative masses of the $\mathrm{LV}$ and $\mathrm{RV}$, heart fibrosis and collagen III/collagen I ratio in the heart of control and L-NAME treated rats did not differ significantly. Similarly, there were no alterations in the cross-sectional area and wall thickness/diameter ratio of the aorta and femoral artery of L-NAME-treated rats when compared to control (Table 1).

\section{NO synthase activity}

Basal NO synthase activity in the aorta, LV and hypothalamus were $5.6 \pm 0.3,3.8 \pm 0.4$ and $38.2 \pm 5.9$ $\mathrm{pmol} / \mathrm{min} / \mathrm{mg}$, respectively (Figs 2A, 2B and 2C). Eight weeks lasting low-dose L-NAME treatment led to a significant elevation of NO synthase activity in the aorta and LV by approximately $43 \%$ and $45 \%(\mathrm{p}<0.007) v s$. control values while there were no significant changes in hypothalamic NO synthase activity. 
Table 1 Biometric and morphological parameters of control and L-NAME-treated rats.

\begin{tabular}{|c|c|c|c|}
\hline & & $\begin{array}{l}\text { Control } \\
\mathrm{n}=8\end{array}$ & $\begin{array}{l}\text { L-NAME } \\
\mathrm{n}=7\end{array}$ \\
\hline Final BM (g) & & $374 \pm 5$ & $382 \pm 6$ \\
\hline$L V / B M(m g / g)$ & & $1.29 \pm 0.03$ & $1.31 \pm 0.04$ \\
\hline$R V / B M(m g / g)$ & & $0.48 \pm 0.02$ & $0.50 \pm 0.02$ \\
\hline \multirow[t]{2}{*}{ Heart } & Fibrosis $(\%$ ) & $12.53 \pm 1.74$ & $10.20 \pm 1.98$ \\
\hline & $\mathrm{Col} \mathrm{III/Col} \mathrm{I}$ & $49.33 \pm 2.05$ & $55.38 \pm 2.96$ \\
\hline \multirow[t]{2}{*}{ Aorta } & $W T / I D$ & $65.50 \pm 2.50$ & $71.00 \pm 2.45$ \\
\hline & $C S A\left(\mu m^{2}\right)$ & $534 \pm 30$ & $518 \pm 40$ \\
\hline \multirow[t]{2}{*}{ Femoral a. } & $W T / I D$ & $94.05 \pm 10.25$ & $108.11 \pm 17.04$ \\
\hline & $C S A\left(\mu m^{2}\right)$ & $63.8 \pm 11$ & $46.5 \pm 10$ \\
\hline
\end{tabular}

Results are presented as mean \pm SEM. BM - body mass, LV - left ventricle, RV - right ventricle, Col - collagen, WT - wall thickness, ID - internal diameter, CSA - cross sectional area
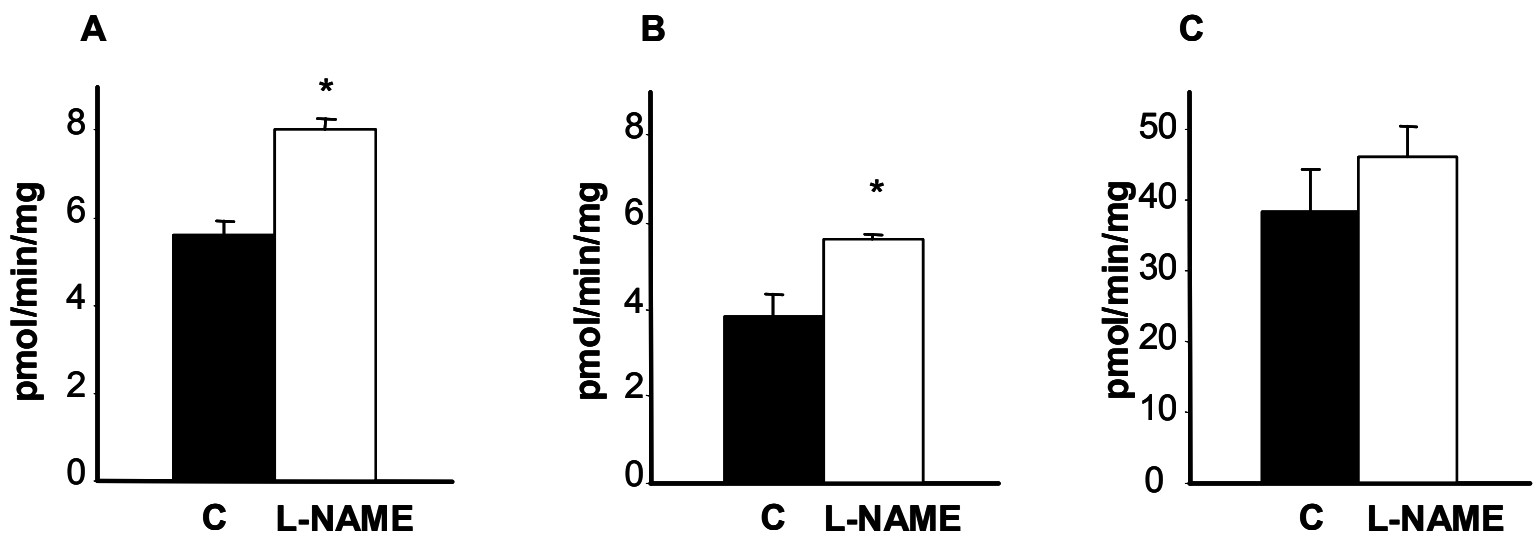

Fig. 2. Effect of chronic low-dose L-NAME treatment on nitric oxide synthase activity in the aorta (A), left ventricle (B), and hypothalamus $(C)$ of rats. Results are presented as mean \pm SEM. $* p<0.007$ vs. control. $C-$ control

Vascular function

Maximal acetylcholine-induced vasodilatation of the femoral artery (Fig. 3A) observed in control rats was $88 \pm 3 \%$, which was significantly lower than in the L-NAME-treated rats $(105 \pm 3 \%, \mathrm{p}<0.05)$. Maximal serotonin-induced vasoconstriction of the femoral artery in control rats (Fig. 3B) was $19.8 \pm 2.7 \mathrm{mN} / \mathrm{mm}$ and L-NAME reduced it to $13.9 \pm 1.8 \mathrm{mN} / \mathrm{mm}(\mathrm{p}<0.03)$.

\section{Discussion}

The most important finding of this study was that the NO synthase inhibitor L-NAME was paradoxically able to increase NO production in the left ventricle and aorta of normotensive rats in vivo when administered in a low dose and for a long time. Chronic low-dose L-NAME-treatment also resulted in augmentation of the endothelium-dependent vasorelaxation and reduced vasoconstriction of the femoral artery. Additionally, no negative effects of L-NAME on the morphological parameters of the heart, aorta and femoral artery were observed.

Several studies addressed the role of NO in the regulation of cardiac and vascular functions using pharmacological inhibition of $\mathrm{NO}$ production in normotensive rats. Administration of high doses of L-NAME (50 -100 mg/kg/day) for 6-8 weeks increased BP by about 40-80 \% (Arnal et al. 1992, Ribeiro et al. 1992, Kristek et al. 1996, Mandarim-de-Lacerda and Pereira 2001). Similar elevation of BP was observed using lower doses of L-NAME (10-20 mg/kg/day) for 4-8 weeks (Arnal et al. 1992, Delacretaz et al. 1994, Ferreira- 

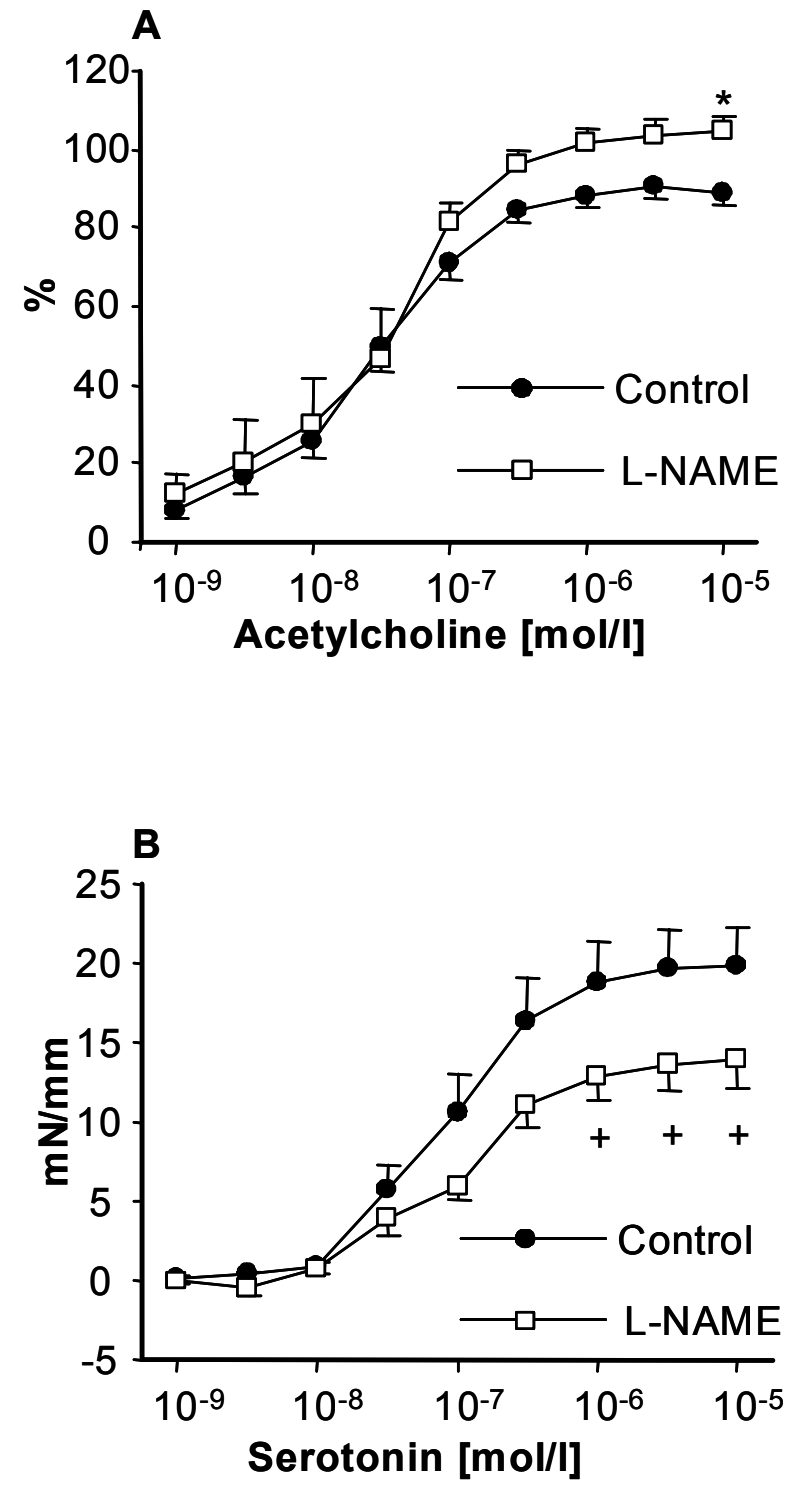

Fig, 3. Effect of chronic low-dose L-NAME treatment on acetylcholine-induced vasorelaxation (A) and serotonin-induced vasoconstriction (B) of the femoral artery. Results are presented as mean \pm SEM. $* p<0.05$ vs. control, ${ }^{+} p<0.03$ vs. control.

Melo et al. 2006). In our previous study, approximately $27 \%$ elevation of BP was observed after the first day of L-NAME administration at the dose of $40 \mathrm{mg} / \mathrm{kg} / \mathrm{day}$ (Pecháňová et al. 1997). However, low doses of L-NAME $(1 \mathrm{mg} / \mathrm{kg} /$ day for 25 days and $2 \mathrm{mg} / \mathrm{kg} /$ day for 7 days) had no significant effect on BP of normotensive rats (Ralay Ranaivo et al. 2004, Arnal et al. 1992). A mechanism responsible for the increase of $\mathrm{BP}$ during L-NAME-treatment is associated with NO deficiency and alterations in various blood pressure regulating systems. Several authors observed elevation of vasoconstriction and attenuation of vasorelaxation in different parts of the vascular tree, increased sympathetic activity and alterations in renin-angiotensin system in L-NAME treated rats (Jover et al. 2001, Bernátová et al. 2002, Kuneš et al. 2004, Rossoni et al. 2007). These metabolic and hemodynamic changes were associated with the development of left ventricular hypertrophy, heart fibrosis, necrosis and protein remodelling, as well as with vascular wall hypertrophy (Babál et al. 1997, FerreiraMelo et al. 2006, Pereira and Mandarim-de-Lacerda 1999, Bernátová et al. 2000, Šimko et al. 2007 b).

In this study, administration of low doses of L-NAME $(\sim 1.5 \mathrm{mg} / \mathrm{kg} /$ day $)$ resulted in a transient mild elevation of BP after three and six weeks of treatment and an extension of treatment to eight weeks resulted in normalization of BP. This was associated with elevation of NO synthase activity in the left ventricle and aorta. Although elevated NOS activity in the aorta does not necessarily mean improvement of NO bioavailability in the femoral artery, the augmentation of endotheliumdependent vasorelaxation along with the decrease of vasoconstriction are indicative of elevated NO availability also in this artery (Dabire et al. 1990). The increase of NO production may result from the negative feedback regulation between $\mathrm{NO}$ and its own production. In addition to the studies which used exogenous $\mathrm{NO}$ donors, Grumbach et al. (2005) have recently observed that eNOS promoter activity and mRNA transcription in bovine aortic endothelial cells were increased in the presence of the NOS inhibitor L-NAME. However, to our knowledge, our study is the first to show that long-term administration of low doses of NO synthase inhibitor may induce improvement of $\mathrm{NO}$ production in the rat heart and aorta in vivo and simultaneously influence vascular function. Based on the elevation of blood pressure after the third and sixth week of L-NAME treatment, we assume that the low doses of L-NAME led to a transient mild NO deficiency, which in turn activated NO production. Thus, our data suggest that chronic low-dose L-NAME administration could provide a useful tool for activation of NO production in vivo. On the other hand, an important limitation of using L-NAME may result from the fact that L-NAME can induce cardiac fibrosis and vascular wall hypertrophy independently of blood pressure and thus impair vascular function and accelerate the development of hypertension (Bernátová et al. 1999a). Nevertheless, as observed in this study, low dose of L-NAME had no negative effect on the structure of the heart and vasculature. These findings suggest that longterm administration of low doses of L-NAME could be used to increase NO synthesis in contrast to 
supplementation with exogenous NO donors, which may inhibit endogenous NO production.

In conclusion, the results showed that chronic administration of the low doses of L-NAME activated NO synthesis in the cardiovascular system without modifying central NO synthesis. In addition, low doses of L-NAME enhanced endothelium-dependent vasorelaxation and reduced vasoconstriction of the femoral artery. The results provide evidence for negative feedback regulation of NO synthesis by NO in normotensive rats in vivo. However, more experiments are needed to elucidate whether this regulatory mechanism is operating only in physiological conditions or if it may be used to increase endogenous NO production (directly or after some modification in the dosage and/or duration of treatment) in pathological conditions, such as hypertension or ischemic heart disease.

\section{Acknowledgement}

This study was supported by APVT-51-018004 and VEGA 2/7064/27. The authors thank Mrs. Y. Hanáčková and Mrs. J. Pet'ová for their excellent technical assistance. Preliminary studies were presented at "Proceedings of Czech and Slovak Physiological Societies”, February 7-9, 2006, Prague, Czech Republic (Púzserová et al. 2006b).

\section{References}

ARNAL JF, WARIN L, MICHEL JB: Determinants of aortic cyclic guanosine monophosphate in hypertension induced by chronic inhibition of nitric oxide synthase. J Clin Invest 90: 647-652, 1992.

BABÁL P, PECHÁŇOVÁ O, BERNÁTOVÁ I, ŠTVRTINA S: Chronic inhibition of NO synthesis produces myocardial fibrosis and arterial media hyperplasia. Histol Histopathol 12: 623-629, 1997.

BERNÁTOVÁ I, PECHÁŇOVÁ O, KRISTEK F: Mechanism of structural remodelling of the rat aorta during longterm NG-nitro-L-arginine methyl ester treatment. Jpn J Pharmacol 81: 99-106, 1999a.

BERNÁTOVÁ, PECHÁŇOVÁ O, ŠIMKO F: Effect of captopril in L-NAME-induced hypertension on the rat myocardium, aorta, brain and kidney. Exp Physiol 84: 1095-1105, 1999 b.

BERNÁTOVÁ I, PECHÁŇOVÁ O, PELOUCH V, ŠIMKO F: Regression of chronic L-NAME-treatment-induced left ventricular hypertrophy: effect of captopril. J Mol Cell Cardiol 32: 177-185, 2000.

BERNÁTOVÁ I, PECHÁŇOVÁ O, BABÁL P, KYSELÁ S, ŠTVRTINA S, ANDRIANTSITOHAINA R: Wine polyphenols improve cardiovascular remodeling and vascular function in NO-deficient hypertension. Am $J$ Physiol 282: H942-H948, 2002.

BREDT DS, SNYDER SH: Isolation of nitric oxide synthetase, a calmodulin-requiring enzyme. Proc Natl Acad Sci USA 87: 682-685, 1990.

COHEN GA, HOBBS AJ, FITCH RM, ZINNER MJ, CHAUDHURI G, IGNARRO LJ: Nitric oxide regulates endothelium-dependent vasodilator responses in rabbit hindquarters vascular bed in vivo. Am J Physiol 271: H133-H139, 1996.

DABIRE H, CHERQUI C, SAFAR M, SCHMITT H: Haemodynamic aspects and serotonin. Clin Physiol Biochem 8 (Suppl 3): 56-63, 1990.

DELACRETAZ E, HAYOZ D, OSTERHELD MC, GENTON CY, BRUNNER HR, WAEBER B: Long-term nitric oxide synthase inhibition and distensibility of carotid artery in intact rats. Hypertension 23: 967-970, 1994.

DOLBER PC, SPACH MS: Conventional and confocal fluorescence microscopy of collagen fibers in the heart. J Histochem Cytochem 41: 465-469, 1993.

FERREIRA-MELO SE, YUGAR-TOLEDO JC, COELHO OR, DE LUCA IM, TANUS-SANTOS JE, HYSLOP S, IRIGOYEN MC, MORENO H, JR: Sildenafil reduces cardiovascular remodeling associated with hypertensive cardiomyopathy in NOS inhibitor-treated rats. Eur J Pharmacol 542: 141-147, 2006.

FIALOVÁ M, DLUGOŠOVÁ K, OKRUHLICOVÁ L, KRISTEK F, MANOACH M, TRIBULOVÁ N: Adaptation of the heart to hypertension is associated with maladaptive gap junction connexin-43 remodelling. Physiol Res 57: in press, 2008.

GEROVÁ M, KRISTEK F: Efficiency of NO donors in substituting impaired endogenous NO production: a functional and morphological study. Physiol Res 50: 165-173, 2001. 
GEROVÁ M, TÖRÖK J, PECHÁŇOVÁ O, MATÚŠKOVÁ J: Rilmenidine prevents blood pressure increase in rats with compromised nitric oxide production. Acta Pharmacol Sin 25: 1640-1646, 2004.

GRISCAVAGE JM, HOBBS AJ, IGNARRO LJ: Negative modulation of nitric oxide synthase by nitric oxide and nitroso compounds. Adv Pharmacol 34: 215-234, 1995.

GRUMBACH IM, CHEN W, MERTENS SA, HARRISON DG: A negative feedback mechanism involving nitric oxide and nuclear factor kappa-B modulates endothelial nitric oxide synthase transcription. J Mol Cell Cardiol 39: 595-603, 2005.

GUIX FX, URIBESALGO I, COMA M, MUNOZ FJ: The physiology and pathophysiology of nitric oxide in the brain. Prog Neurobiol 76: 126-152, 2005.

JOVER B, HERIZI A, CASELLAS D, MIMRAN A: Influence of irbesartan and enalapril on changes of renal function associated with the established phase of l-NAME hypertension. J Hypertens 19: 2039-2046, 2001.

KRISTEK F, GEROVÁ M, DEVÁT L, VARGA I: Remodelling of septal branch of coronary artery and carotid artery in L-NAME treated rats. Physiol Res 45: 329-333, 1996.

KUNEŠ J, HOJNÁ S, KADLECOVÁ M, DOBEŠOVÁ Z, RAUCHOVÁ H, VOKURKOVÁ M, LOUKOTOVÁ J, PECHÁŇOVÁ O, ZICHA J: Altered balance of vasoactive systems in experimental hypertension: the role of relative NO deficiency. Physiol Res 53 (Suppl 1): S23-S34, 2004.

MANDARIM-DE-LACERDA CA, PEREIRA LM: Renal cortical remodelling by NO-synthesis blockers in rats is prevented by angiotensin-converting enzyme inhibitor and calcium channel blocker. J Cell Mol Med 5: 276283, 2001.

OKRUHLICOVÁ L, TRIBULOVÁ N, BERNÁTOVÁ I, PECHÁŇOVÁ O: Induction of angiogenesis in NO-deficient rat heart. Physiol Res 49: 71-76, 2000.

PARK SK, LIN HL, MURPHY S: Nitric oxide regulates nitric oxide synthase-2 gene expression by inhibiting NFkappaB binding to DNA. Biochem J 322: 609-613, 1997.

PAULIS L, ZICHA J, KUNEŠ J, HOJNÁ S, KOJŠOVÁ S, PECHÁŇOVÁ O, ŠIMKO F: Regression of L-NAMEinduced hypertension: The role of NO-pathway and endothelium-derived constricting factor. $J$ Hypertens 24 (Suppl 4): S7, 2006.

PECHÁŇOVÁ O, ŠIMKO F: The role of nitric oxide in the maintenance of vasoactive balance. Physiol Res 56 (Suppl 2): S7-S16, 2007.

PECHÁŇOVÁ O, BERNÁTOVÁ I, PELOUCH V, ŠIMKO F: Protein remodelling of the heart in NO-deficient hypertension: the effect of captopril. J Mol Cell Cardiol 29: 3365-3374, 1997.

PECHÁŇOVÁ O, BERNÁTOVÁ I, PELOUCH V, BABÁL P: L-NAME-induced protein remodeling and fibrosis in the rat heart. Physiol Res 48: 353-362, 1999.

PEREIRA LM, MANDARIM-DE-LACERDA CA: Myocardial microcirculation stereological changes in rats subjected to nitric oxide synthesis inhibition. Pathol Res Pract 195: 177-181, 1999.

PÚZSEROVÁ A, CSIZMADIOVÁ Z, ANDRIANTSITOHAINA R, BERNÁTOVÁ I: Vascular effects of red wine polyphenols in chronic stress-exposed Wistar-Kyoto rats. Physiol Res 55 (Suppl 1): S39-S47, 2006a.

PÚZSEROVÁ A, KOPINCOVÁ J, CSIZMADIOVÁ Z, BERNÁTOVÁ I: Effect of chronic low dose L-NAME treatment and stress on cardiovascular system of borderline hypertensive rats. Physiol Res 55: 39P, $2006 \mathrm{~b}$.

RALAY RANAIVO H, DIEBOLT M, ANDRIANTSITOHAINA R: Wine polyphenols induce hypotension, and decrease cardiac reactivity and infarct size in rats: involvement of nitric oxide. Br J Pharmacol 142: 671-678, 2004.

RIBEIRO MO, ANTUNES E, DE NUCCI G, LOVISOLO SM, ZATZ R: Chronic inhibition of nitric oxide synthesis. A new model of arterial hypertension. Hypertension 20: 298-303, 1992.

ROSSONI G, MANFREDI B, DE GC, V, BERTI M, GUAZZI M, BERTI F: Sildenafil reduces L-NAME-induced severe hypertension and worsening of myocardial ischaemia-reperfusion damage in the rat. $\mathrm{Br} J$ Pharmacol 150: 567-576, 2007.

ŠIMKO F: Is NO the king? Pathophysiological benefit with uncertain clinical impact. Physiol Res 56 (Suppl 2): S1-S6, 2007. 
ŠIMKO F, ŠIMKO J: The potential role of nitric oxide in the hypertrophic growth of the left ventricle. Physiol Res 49: 37-46, 2000.

ŠIMKO F, MATÚŠKOVÁ J, LUPTÁK I, PINČÍKOVÁ T. KRAJČÍROVIČOVÁ K, ŠTVRTINA S, POMŠÁR J, PELOUCH V, PAULIS L, PECHÁŇOVÁ O: Spironolactone differently influences remodeling of the left ventricle and aorta in L-NAME-induced hypertension. Physiol Res 56 (Suppl 2): S25-S32, 2007a.

ŠIMKO F, POTÁČOVÁ A, PELOUCH V, PAULIS L, MATÚŠKOVÁ J, KRAJČÍROVIČOVÁ K, PECHÁŇOVÁ O, ADAMCOVÁ M: Spontaneous, L-arginine-induced and spironolactone induced regression of protein remodeling of the left ventricle in L-NAME-induced hypertension. Physiol Res 56 (Suppl 2): S55-S62, 2007b.

TÖRÖK J, KRISTEK F: Beneficial effect of pentaerythrityl tetranitrate on functional and morphological changes in the rat thoracic aorta evoked by long-term nitric oxide synthase inhibition. Vascul Pharmacol 38: 177-182, 2002.

TRIBULOVÁ N, OKRUHLICOVÁ L, BERNÁTOVÁ I, PECHÁŇOVÁ O: Chronic disturbances in NO production results in histochemical and subcellular alterations of the rat heart. Physiol Res 49: 77-88, 2000.

VAZIRI ND, WANG XQ: cGMP-mediated negative-feedback regulation of endothelial nitric oxide synthase expression by nitric oxide. Hypertension 34: 1237-1241, 1999.

VICKROY TW, MALPHURS WL: Inhibition of nitric oxide synthase activity in cerebral cortical synaptosomes by nitric oxide donors: evidence for feedback autoregulation. Neurochem Res 20: 299-304, 1995.

\section{Corresponding author}

Iveta Bernátová, PhD. Institute of Normal and Pathological Physiology, Centre of Excellence for Cardiovascular Research, Slovak Academy of Sciences, Sienkiewiczova 1, Bratislava 813 71. E-mail: Iveta.Bernatova@savba.sk 